\title{
A prospective study of demographic profile, risk factors and pregnancy outcome in Hepatitis $B$ and Hepatitis $C$ virus positive pregnant women in a tertiary care centre
}

\author{
Arti Sharma $^{1 *}$, Shubhra Agarwal ${ }^{2}$, Garima Bajpai ${ }^{2}$, Anupriya Singh², Nikita Agarwal', \\ Shweta Mishra ${ }^{1}$
}

\begin{abstract}
${ }^{1}$ Department of Obstetrics and Gynecology, Shri Guru Ram Rai Institute of Medical and Health Sciences, Dehradun, Uttarakhand, India

${ }^{2}$ Department of Obstetrics and Gynecology, Teerthankar Mahaveer Medical College and Research Centre, Moradabad, Uttar Pradesh, India
\end{abstract}

Received: 14 April 2020

Accepted: 05 May 2020

\section{*Correspondence:}

Dr. Arti Sharma,

E-mail: artishubh@yahoo.com

Copyright: ( $)$ the author(s), publisher and licensee Medip Academy. This is an open-access article distributed under the terms of the Creative Commons Attribution Non-Commercial License, which permits unrestricted non-commercial use, distribution, and reproduction in any medium, provided the original work is properly cited.

\begin{abstract}
Background: Viral hepatitis is the most common liver disease in pregnancy and is also the most common cause of jaundice in pregnancy in tropical countries. Risk factors for transmission are intravenous drug abuse, surgical and dental procedures done without adequate sterilization of instruments, sexual route etc. Early diagnosis and management can prevent maternal and fetal complications. This study was done to evaluate the frequency, risk factors and pregnancy outcome in hepatitis B virus (HBV) and hepatitis C virus (HCV) positive antenatal women.

Methods: This case control study was conducted in Teerthankar Mahaveer Medical College and Research Centre, Moradabad, Uttar Pradesh, India from January 2017 to June 2018 on total 2511 pregnant women. The serum samples were checked for presence of hepatitis B surface antigen ( $\mathrm{HBsAg}$ ) and presence of IgG antibodies to HCV. Analysis of sociodemographic profile, risk factors and pregnancy outcome were done in all HBV and HCV positive women.

Results: Out of 2511 pregnant women, 292 were tested positive for hepatitis. Maximum number of women were in the age group of 21-30 years. Most of the seropositive women were multipara. Frequency of positivity was maximum for HCV $(67.1 \%)$. The risk factors for transmission in study population were intravenous drug abuse, blood transfusion, history of surgery and tattooing.

Conclusions: Hepatitis infection rate is increasing. Universal screening for HBV and HCV can be recommended in pregnant women in developing countries. Education and awareness of public and health care workers can reduce the risk of transmission.
\end{abstract}

Keywords: Antenatal women, Hepatitis B virus, Hepatitis C virus, Transmission

\section{INTRODUCTION}

Hepatitis $\mathrm{B}$ and $\mathrm{C}$ virus are a global health problem. Hepatitis B is a DNA virus which is transmitted by parental route, sexual contact, vertical transmission and through breast milk. Most infected women are asymptomatic. Hepatitis C affects $2-3 \%$ of world's population and in Indian population in pregnancy seroprevalence of anti-HCV is $1.03 \% .^{1,2}$ Risk factors for Hepatitis $\mathrm{C}$ virus include intravenous drug abuse, exposure to blood components, surgeries, sexual transmission but in $40 \%$ cases the cause is unknown. ${ }^{3}$ Hepatitis $\mathrm{C}$ virus positive women can transmit the virus to fetus in $7-8 \%$ cases. ${ }^{4}$ Hepatitis $\mathrm{C}$ virus is mostly diagnosed accidentally and is asymptomatic in 65-75\% patients. Hepatitis $\mathrm{C}$ virus morbidity and mortality is far 
greater than Hepatitis $\mathrm{B}$ virus in terms of chronic hepatitis (70\%), cirrhosis (20-30\%), hepatocellular carcinoma and liver failure. ${ }^{5}$ Perinatal transmission from mother to offspring is relatively low but possible (less than 10\%). ${ }^{6,7}$ Early diagnosis and management can prevent long term fetal and maternal complications. This study was conducted to evaluate the demographic profile, risk factors and pregnancy outcome in Hepatitis B virus (HBV) and Hepatitis C virus (HCV) positive pregnant women in a tertiary care centre.

\section{METHODS}

This case control study was designed in the department of obstetrics and gynecology of Teerthanker Mahaveer Medical College and Research Centre, Moradabad, Uttar Pradesh from January 2017 to June 2018.

\section{Inclusion criteria}

- All pregnant women coming to hospital were screened for HBV and HCV infection. A predesigned proforma was used for collecting information regarding sociodemographic characters, risk factors and pregnancy outcome in seropositive women.

\section{Exclusion criteria}

- Nonpregnant women coming to hospital for gynecological problem or some other problem.

A total of 2511 pregnant women presenting in the antenatal OPD were included in the study. After taking informed consent the serum samples were checked for the presence of hepatitis B surface antigen (HBsAg) using one step rapid visual test for the qualitative detection of HBsAg in human serum, if came positive is confirmed by Microwell HBsAg ELISA (M/S). Mitra and Co. Pvt. Ltd., New Delhi. which is a direct non-competitive solid phase enzyme immunoassay for the detection of HBsAg in serum or plasma. The serum samples were checked for the presence of $\operatorname{IgG}$ antibodies to $\mathrm{HCV}$ using fourth generation HCV TRI DOT test kit, (M/S). Mitra 7 Co. Pvt. Ltd, New Delhi third generation ELISA for the detection of antibodies against $\mathrm{HCV}$ in human serum or plasma. Microwells were coated with $\mathrm{HCV}$-specific recombinant antigens for the putative C-core (structural), E1nad E2 (envelop proteins), NS3, NS4 and NS5 (nonstructural) regions of the $\mathrm{HCV}$ genome.

Those women who were tested positive for HBV and $\mathrm{HCV}$ were further followed up. Maternal factors analysis done in terms of their age, parity, educational status, risk factors, mode of delivery and pregnancy outcome. Results were calculated in frequency and percentage.

\section{RESULTS}

This study was carried on 2511 pregnant women. All were tested for HBV and HCV seroprevalence. A total of
292 women tested positive for hepatitis. 104 (35.6\%) tested positive for HBV and $196(67.1 \%)$ tested positive for HCV. 8 women $(2.7 \%)$ were positive for both HBV and HCV. Prevalence of HBV was $4.1 \%$ and $\mathrm{HCV}$ was $7.8 \%$ (Table1).

Table 1: Burden of Hepatitis in study population.

\begin{tabular}{|lll|}
\hline Positivity & Cases $(\mathbf{N}=292)$ & $\%$ \\
\hline Hepatitis B & 104 & $35.6 \%$ \\
\hline Hepatitis C & 196 & $67.1 \%$ \\
\hline Both & 8 & $2.7 \%$ \\
\hline
\end{tabular}

Maximum women (239) were in the age group of 21-30 years (Table 2).

Table 2: Age distribution of patients.

\begin{tabular}{|lllll|}
\hline $\begin{array}{l}\text { Age } \\
\text { (years) }\end{array}$ & $\begin{array}{l}\text { Cases } \\
(\mathbf{N}=292)\end{array}$ & $\%$ & $\begin{array}{l}\text { Controls } \\
(\mathbf{N}=2219)\end{array}$ & $\%$ \\
\hline $17-20$ & 5 & $1.7 \%$ & 44 & $2 \%$ \\
\hline $21-25$ & 133 & $45.5 \%$ & 1133 & $51.1 \%$ \\
\hline $26-30$ & 106 & $36.3 \%$ & 665 & $30 \%$ \\
\hline $31-35$ & 41 & $14.04 \%$ & 290 & $13.1 \%$ \\
\hline$>35$ & 7 & $2.3 \%$ & 87 & $3.8 \%$ \\
\hline
\end{tabular}

Table 3: Parity of patients.

\begin{tabular}{|lllll|}
\hline Parity & $\begin{array}{l}\text { Cases } \\
(\mathbf{N}=292)\end{array}$ & $\%$ & $\begin{array}{l}\text { Controls } \\
(\mathbf{N}=2219)\end{array}$ & $\%$ \\
\hline Primipara & 64 & $21.9 \%$ & 540 & $24.3 \%$ \\
\hline Multipara & 228 & $78.1 \%$ & 1679 & $75.7 \%$ \\
\hline
\end{tabular}

There were 64 (21.9\%) nullipara and 228 (78.1\%) multipara who had positive seroprevalence (Table 3 ).

Table 4: Educational status of patients.

\begin{tabular}{|lllll|}
\hline Status & $\begin{array}{l}\text { Cases } \\
(\mathrm{N}=292)\end{array}$ & $\%$ & $\begin{array}{l}\text { Controls } \\
(\mathbf{N}=2219)\end{array}$ & $\%$ \\
\hline Up to metric & 272 & $93.1 \%$ & 2022 & $91.1 \%$ \\
\hline$>12^{\text {th }}$ & 20 & $6.9 \%$ & 197 & $8.9 \%$ \\
\hline
\end{tabular}

Total $272(93.1 \%)$ of the women were educated up to metric while $20(6.9 \%)$ women were educated more than that (Table 4).

Out of total 292 women, $150(51.4 \%)$ had vaginal delivery, $92(31.5 \%)$ had caesarean section, $24(8.2 \%)$ women came with incomplete abortion and dilatation and curettage (D and C) was done. 9 (3.1\%) women had exploratory laparotomy for rupture tubal ectopic pregnancy. 17 (5.8\%) women lost to follow up (Table 5).

The risk factors for transmission were intravenous drug abuse $(87.7 \%)$, blood transfusion $(43.8 \%)$, history of D and C (19.2\%) and previous surgery $(20.5 \%)$. History of tattooing was present in $34(11.6 \%)$ women (Table 6). 
Table 5: Mode of delivery and pregnancy outcome.

\begin{tabular}{|lllll|}
\hline Mode of delivery and other outcome & Cases $(\mathbf{N}=\mathbf{2 9 2})$ & $\%$ & Controls $(\mathbf{N}=\mathbf{2 2 1 9})$ & $\%$ \\
\hline Vaginal & 150 & $51.4 \%$ & 1010 & $45.5 \%$ \\
\hline Caesarean & 92 & $31.5 \%$ & 741 & $33.4 \%$ \\
\hline Check curettage & 24 & $8.2 \%$ & 202 & $9.1 \%$ \\
\hline Exploratory laparotomy & 9 & $3.1 \%$ & 78 & $3.5 \%$ \\
\hline Lost to follow-up & 17 & $5.8 \%$ & 188 & $8.5 \%$ \\
\hline
\end{tabular}

Table 6: Risk factors analysis in study population.

\begin{tabular}{|lllll|}
\hline Risk factors & Cases $(\mathbf{N}=\mathbf{2 9 2})$ & $\%$ & Controls $(\mathbf{N}=\mathbf{2 2 1 9})$ & $\%$ \\
\hline History of parenteral drug abuse & 256 & $87.7 \%$ & 1232 & $55.5 \%$ \\
\hline History of blood transfusion & 128 & $43.8 \%$ & 513 & $23.1 \%$ \\
\hline History of abortion & 56 & $19.2 \%$ & 415 & $18.7 \%$ \\
\hline History of D and C & 56 & $19.2 \%$ & 344 & $15.5 \%$ \\
\hline History of previous surgery & 60 & $20.5 \%$ & 313 & $14.1 \%$ \\
\hline History of tattooing & 34 & $11.6 \%$ & 180 & $8.1 \%$ \\
\hline
\end{tabular}

\section{DISCUSSION}

In this study seroprevalence of HCV in antenatal women was $7.8 \%$, which is higher than other epidemiologic studies. ${ }^{8-10}$ Prevalence in western countries ranges from 0.14 to $4.4 \%$ which is comparable to developing countries like India. ${ }^{11,12}$ Higher prevalence of Hepatitis at study tertiary care centre could be attributed to use of contaminated needles and syringes in rural areas before referral to study centre. In this study the prevalence in younger women was found to be higher up to the age of 21-30 years is similar to the other studies. ${ }^{13}$ The prevalence of anti-HCV in multiparous women was more than nulliparous in this study which could be due to past pregnancies, hospital admissions, past surgeries, obstetrical procedures, and blood transfusions. Blood transfusion and parenteral drug abuse were the most important risk factors in this study as observed in previous studies. ${ }^{14,15}$ There was no significant difference in birth weight, neonatal jaundice, birth asphyxia, small for gestational age babies among the study, and control group as observed in previous studies. ${ }^{16-18}$ In this study, all patients had normal liver function tests which supports the hypothesis of immune-mediated effect of pregnancy on liver cell necrosis in anti-HCV positive women. ${ }^{17}$ In a study from Uttarakhand, seroprevalence of Hepatitis-C among pregnant women was $0.89 \%$. Among the risk factors studied, previous surgery and blood transfusion were found to be the important risk factors observed in $16(25.80 \%)$ and $5(8.06 \%)$ of anti-HCV positive pregnant women. ${ }^{19}$ In another study $39(0.48 \%)$ women were found to be HBsAg carriers. Furthermore, prevalence was much lower in German-born women (0.2\%) in comparison to Asian-born women $(9.1 \%)$ and these women with HBsAg had no significantly increased prevalence of adverse pregnancy outcomes. ${ }^{20}$
Although in India universal screening for Hepatitis $\mathrm{C}$ is not recommended in pregnancy but at a set up like ours where anemia is prevalent, repeated $\mathrm{D}$ and $\mathrm{C}$ are common in the periphery using contaminated syringes and needles Hepatitis B and C prevalence increases. Although in 35\% cases the risk factor remains unknown but adequate sterilization of surgical instruments and intensive screening of blood and component for transfusion and mass campaign creating awareness in the public, and health workers can reduce the incidence of this infection.

\section{CONCLUSION}

Hepatitis infection prevalence is increasing and in 35\% cases the risk factors are unknown. Universal screening can be recommended in pregnant women to prevent adverse effects of the infection. Education and awareness of general population, proper screening of blood and components for transfusion and adequate sterilization of surgical instruments and vaccination are key to reduce the infection.

\section{Funding: No funding sources}

Conflict of interest: None declared

Ethical approval: The study was approved by the Institutional Ethics Committee

\section{REFERENCES}

1. Baldo V, Baldovin T, Trivello R. Epidemiology of HCV infection. Curr Pharm Des. 2008;14:1646-54.

2. Kumar A, Sharma KA, Gupta RK. Prevalence and risk factors for hepatitis $\mathrm{C}$ virus among pregnant women. Indian J Med Res. 2007;126:211-5.

3. Conte D, Fraquelli M, Prati D, Colucci A, Minola E. Prevalence and clinical course of chronic hepatitis $\mathrm{C}$ virus (HCV) infection and rate of $\mathrm{HCV}$ vertical 
transmission in a cohort of 15,250 pregnant women. Hepatol. 2000;31:751-5.

4. ACOG Educational Bulletin. Viral hepatitis in pregnancy. Int J Gynaecol Obstet. 1998;63:195-202.

5. Ericksen NL. Perinatal consequences of Hepatitis C. Clin Obstet Gynecol. 1999;42:121-33.

6. Summaries for patients. Hepatitis $\mathrm{C}$ virus infection in United States 1999 through 2002. Am Intern Med. 2006;144:120.

7. Zhou DX, Tang JW, Chu IM, Cheung JL, Tang NL, Tam JS, et al. Hepatitis C virus genotype distribution among intravenous drugs user and the general population in Hong Kong. J Med Virol. 2006;78(5):574-81.

8. Shah NH, Shabbir G. A review of published literature on Hepatitis $\mathrm{B}$ and $\mathrm{C}$ virus prevalence in Pakistan. JCPS Pakistan. 2002;12:368-71.

9. Garner JJ, Gaughwin M, Dodding J, Wilson K. Prevalence of Hepatitis $\mathrm{C}$ infection in pregnant women in South Australia. Med J Aust. 1997;167(9):470-2.

10. Marranconi F. Fabris P, Stecca C, Zampieri L, Battini MC, DiFabrizio N, et al. Prevalence of anti$\mathrm{HCV}$ and risk factor for hepatitis c virus infection in healthy pregnant women. Infect. 1994;22:333-7.

11. Ward C, Tudor-Williams G, Cotzias T, Hargreaves S, Regan L, Foster GR. Prevalence of hepatitis C among pregnant women attending an inner London obstetric department: uptake and acceptability of named antenatal testing. Gut. 2000;47(2):277-80.

12. Silverman NS, Jenkin BK, Wu C, McGillen P, Knee G. Hepatitis $C$ virus in pregnancy: seroprevalence and risk factors for infection. Am J Obstet Gynecol. 1993;169:583-7.

13. Chakarvati A, Kar P, Gupta RK, Sharma KA, Kumar A. Prevalence and risk factor for Hepatitis $C$ virus among pregnant women. Indian $\mathrm{J}$ Med Res. 2007;126:211-25.
14. Raptopoulou, Gigi M, Orphanou E, Lalla TH, Lita A, Garifallos A. Prevalence of Hepatitis C virus infection on cohort of pregnant women in Northern Greece and transmission of HCV from mother to child. Eur J Epidemiol. 2001;17:236-6.

15. Jadoon HA, Ahmed Z. Prevalence of anti-HCV in blood donors of hazara (NWFP) Pakistan. J Med Res. 1999;38:7-9.

16. Jabeen T, Cannon B, Hogan J, Crowley M, Devereux C, Fanning L, et al. Pregnancy and pregnancy outcome in hepatitis C type 1b. QJM. 2000;93:597601.

17. Awan NS, Asraf N, Nayyar S. Obstetrics and perinatal outcome; risk factors for hepatitis B and C transmission. Professional Med J. 2006;13(4):511-6.

18. Marti C, Pena JM, Bates I, Madero R, De Jose I, Pallardo LF, et al. Obstetric and perinatal complications in HIV-infected women. Analysis of cohort of 167 pregnancies between 1997 and 2003. Acta Obstet Gynecol Scand. 2007;86(4):409-15.

19. Upreti P, Singh RK, Arya V. Burden of HCV infection among pregnant women with assessment of risk factors and pregnancy outcome in HCV infected: A hospital-based study from Uttarakhand. JMSCR. 2017;5(1):17249-56.

20. Lobstein S, Faber R, Tillmann HL. Prevalence of hepatitis $\mathrm{B}$ among pregnant women and its impact on pregnancy and newborn complications at a tertiary hospital in the eastern part of Germany. Digest. 2011;83(1-2):76-82.

Cite this article as: Sharma A, Agarwal S, Bajpai G, Singh A, Agarwal N, Mishra S. A prospective study of demographic profile, risk factors and pregnancy outcome in Hepatitis B and Hepatitis C virus positive pregnant women in a tertiary care centre. Int J Reprod Contracept Obstet Gynecol 2020;9:2393-6. 